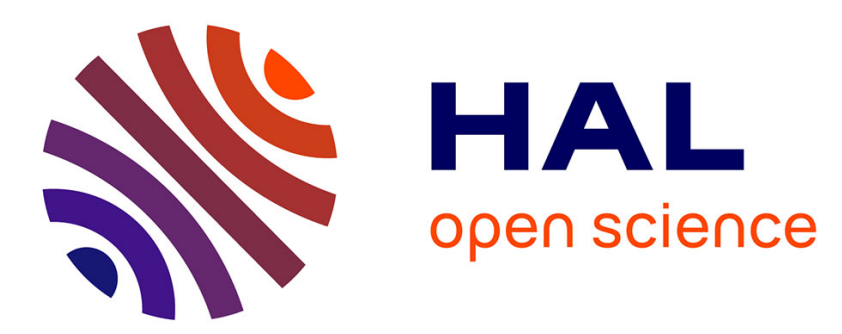

\title{
Dike failure caused by flow overtopping: a comparison of two modelling methods
}

André Paquier, K. El Kadi Abderrezzak

\section{To cite this version:}

André Paquier, K. El Kadi Abderrezzak. Dike failure caused by flow overtopping: a comparison of two modelling methods. 38th IAHR World Congress, Sep 2019, Panama City, Panama. pp.10. hal-02609873

\section{HAL Id: hal-02609873 \\ https://hal.inrae.fr/hal-02609873}

Submitted on 16 May 2020

HAL is a multi-disciplinary open access archive for the deposit and dissemination of scientific research documents, whether they are published or not. The documents may come from teaching and research institutions in France or abroad, or from public or private research centers.
L'archive ouverte pluridisciplinaire HAL, est destinée au dépôt et à la diffusion de documents scientifiques de niveau recherche, publiés ou non, émanant des établissements d'enseignement et de recherche français ou étrangers, des laboratoires publics ou privés. 


\title{
DIKE FAILURE CAUSED BY FLOW OVERTOPPING: A COMPARISON OF TWO MODELLING METHODS
}

\author{
ANDRE PAQUIER(1), KAMAL EL KADI ABDERREZZAK(2,3) \\ (1) Irstea, UR RiverLy, Institut National des Sciences Appliquées de Lyon, Villeurbanne, France \\ andre.paquier@irstea.fr. \\ (2) EDF R\&D, National Laboratory for Hydraulics and Environment, Chatou, France \\ (3) Saint Venant Laboratory for Hydraulics, Chatou, France \\ kamal.el-kadi-abderrezzak@edf.fr
}

\begin{abstract}
In order to model the process of flooding induced by fluvial dike breaching, 2-D shallow water equations are often used. They can be coupled with a sediment transport model simulating the dike erosion and the erosion of the neighbouring bed areas. However, such a model is not dedicated to the specific process of embankment erosion. One may prefer using a specific breach model, simulating the breach expansion and outflow hydrograph, associated to a 2D shallow water model simulating the flood propagation in the areas protected. In the present work, the two approaches are compared on a field case and on laboratory experiments. For the field case, the short overtopping duration involves that the results are very sensitive to the erosion parameters associated to the dike breaching, particularly the critical shear stress necessary for the initiation of surface erosion. The breach development depends on the modelling approach that can favour either the breach deepening or widening. With a fast breach deepening (breach model), the breach peak outflow is high whereas a high breach widening (sediment transport model) yields a peak flow reduced by more than $90 \%$. The laboratory experiments represent a long flood event leading to a total erosion of the dike over a long distance with a large part of the upstream flow being deviated into the floodplain through the breach. The two approaches (breach model and sediment transport model) provide rather similar results and close to the laboratory measurements although the breach model provides faster initial erosion and is less sensitive to the type of erosion rate equations.
\end{abstract}

Keywords: River levee; breach; overtopping; erosion pit; numerical model.

\section{INTRODUCTION}

Along rivers, fluvial dikes (i.e. levees) are built to protect humans and property from flooding events. Overtopping of dikes during an extreme flood may lead to the formation of a breach, eventually creating a very fast inundation. Generally, 2-D shallow water equations are convenient for simulating the flow propagation generated by the dike breaching because the main process is the spreading of water on the land surface. For the breach formation and development, an erosion model is necessary instead of using empirical or regression equations estimating the breach dimensions which are very uncertain because the number of documented events is not enough. ASCE (2011) proposed a review of some breach models and distinguished two groups for overtopping simulations: specific breach models that describe the various steps of the erosion process in a more or less detailed way (e.g. Zhong et al., 2016) and hydro-sedimentary models that associate to the shallow water equations one or several equations for the sediment transport and for the erosion and deposition processes (e.g. Cantero-Chinchilla et al., 2018). In the latter case, the erosion of the levee is calculated by considering the material composing the levee. Comparisons between the breach models are generally provided for dam breaching while the levee breaching conditions may differ a lot because of the upstream variation of the water elevation and the direction of the main flow parallel to the levee crest.

Here below, these two approaches are compared on a field case and on laboratory experiments of levees: for the field case, the breach development is limited by the short duration of the flood, while for the laboratory experiments the breach development stops because most part of the main flow is deviated to the floodplain through the breach. In order to perform the comparison with parameters set as similar as possible, the same hydraulic numerical model is used and only the representations of the breach differ. Moreover, several meshes, sediment transport equations and associated parameters are used because they are likely to provide very different results. The comparison between results includes the breach dimension, the breach flow hydrograph and the consequences in the downstream area in terms of flooding and eventual bed erosion. After the description of the numerical model, the two events are presented together with the sets of parameters used for the modelling. Then, results are provided and discussed. 


\section{DESCRIPTION OF THE NUMERICAL MODEL}

The code Rubar 20 solves 2-D shallow water equations by an explicit finite volume scheme. The second order Godunov-type scheme includes two main steps which consists in, first, estimating the fluxes through edges for the conservative part of the equations, and then, integrating the second member of the equations on the cell surface in order to add the corresponding contribution. The estimate of the flux through one edge is computed by solving a 1-D Riemann problem perpendicularly to the edge (and is replaced by a calculation of the discharge by the flow - elevation equation in case of a hydraulic structure). The discontinuities or fronts, which occur during the propagation immediately downstream of the breach, are included as ordinary points, so that there is no need of any particular drying/wetting treatment (El Kadi Abderrezzak et al., 2009). The calculation mesh mainly consists of quadrilaterals with triangles in order to adapt to a natural topography.

One hydraulic structure is defined as a set of few cells in which the flow enters through one edge and goes out through the same edge or another one, with the flow rate being computed using specific equations (for instance, weir equation). In Rubar 20, the specific breach model Rupro (Paquier, 2007) can be used. In that case, a breach is represented by one or several hydraulic structures depending on the cell sizes. The flow through one of these hydraulic structures is calculated using the Bernoulli equation in a homogeneous channel of which the control cross section shape is evolving depending on the erosion rate $E$. The control section may be circular in case of piping and rectangular in case of overtopping or second phase of piping. The erosion rate $E$ is calculated either using a linear equation of the difference between bottom shear stress $\tau$ and a critical shear stress $\tau_{c r}$ (Eq. [1] in which $M$ is an erosion coefficient) or using the Meyer-Peter and Müller (1948) sediment transport capacity equation (Paquier, 2007) and assuming a constant erosion rate on the bottom or bank areas.

$$
E=M\left(\tau / \tau_{c r}-1\right)
$$

If the size of the computational cells is small, the breach is represented by two sets of several hydraulic structures operating one after the other (erosion starting in one structure as soon as it finished in the previous one), each set being used to simulate either erosion toward upstream or downstream. If the size is coarser, then, only one set or even only one hydraulic structure are used.

In Rubar 20, the 2-D shallow water equations are completed by the following sediment transport equation:

$$
\frac{\partial(C h)}{\partial t}+\frac{\partial\left(C h u_{S}\right)}{\partial x}+\frac{\partial\left(C h v_{S}\right)}{\partial y}=\frac{\partial}{\partial x}\left(h K \frac{\partial C}{\partial x}\right)+\frac{\partial}{\partial y}\left(h K \frac{\partial C}{\partial y}\right)+E
$$

in which $E$ is the rate $(\mathrm{m} / \mathrm{s})$ of bed elevation evolution (erosion if positive or deposition if negative), $C$ the concentration of sediments $\left(\mathrm{m}^{3} / \mathrm{m}^{3}\right), u_{s}$ and $v_{s}$ the sediment velocities $(\mathrm{m} / \mathrm{s})$ in the $x$ and $y$ directions (generally set equal to water velocities), $h$ the water depth $(\mathrm{m}), K$ a diffusion coefficient $\left(\mathrm{m}^{2} / \mathrm{s}\right)$ (equal to the water diffusion coefficient in the present calculations). $E$ can be either calculated from an empirical equation providing the maximum sediment transport capacity (case of bed load) or more simply set proportional (thus called "linear model" here after) to the difference between bottom shear stress and a critical shear stress (Eq. [1] for erosion and Eq. [3] for deposition in which $\alpha$ is a coefficient and $w_{s}$ is the fall velocity of the sediments) or calculated from an equilibrium concentration (Paquier, 2013). $E$ is calculated at each node and then averaged over the cell (or directly calculated at the cell centre and then distributed between the nodes) in order to obtain sediment input or output to fill Eq. [2]. Bed elevation evolves considering $E$ at every time step. Eq. [2] is solved using a first order finite volume scheme and using the same time step as shallow water equations.

$$
E=-\alpha w_{s} C\left(1-\tau / \tau_{c r}\right)
$$

For the two cases described here below, Rubar 20 with Eq. [2] was used to calculate erosion and deposition downstream the breach but the two following approaches were successively tested for the breaches development: either, the breach is represented by a set of hydraulic structures using the Rupro breach model or, the breach is included in the ordinary points for which erosion and deposition are calculated.

\section{DESCRIPTION OF THE SIMULATED CASES}

\subsection{Agly levee failure}

The overtopping of Agly levee during the November 1999 flood in the southern part of France (Paquier et al., 2002) led to the flooding of a wide coastal plain, quite flat in which flow was limited by a lot of embankments. The flood was one of the highest events of the 20th century in the lower reach of the Agly River. During this period, the lower part of the river basin received intense rainfalls (between 200 and $400 \mathrm{~mm}$ within 24 hours). 
The peak discharge reached about $2000 \mathrm{~m}^{3} / \mathrm{s}$ (return period of about 100 years), which was higher than the conveyance of the main channel between the levees in the lower reach (about $1500 \mathrm{~m}^{3} / \mathrm{s}$ ). Although the river overflowed to the floodplain upstream from this reach, the levees were overtopped in a lot of locations and particularly upstream from the last bridge before the sea, which was blocked by wood and other vegetation deposits. Overtopping was one of the cause of flooding of large areas but only with a few centimetres of water. At one location, the overtopping induced dike breaching because of the levee material heterogeneity. Although it occurred at the start of the falling phase of the discharge hydrograph, the breach developed to reach the elevation of the land downstream of the levee and even below because an erosion pit developed at the toe of the levee. This latter breach (about $40 \mathrm{~m}$ wide and $3 \mathrm{~m}$ high on average) suddenly released a two metres high wave that damaged a sewage plant in Saint Laurent de la Salanque and flooded the village. The area in which the influence of the breach was high is limited by the embankments protecting the village from an upstream flooding because the flow can only cross these embankments through a few hydraulic structures dedicated to drainage network or roads.

A 2-D model of the whole floodplain (18,568 cells) was built to simulate the 1999 flood event (Paquier, 2015). The cell size varies from about $5 \mathrm{~m}$ on the levees to $200 \mathrm{~m}$ in the floodplain. Although there was heavy rain over the area, the water inputs were limited to the discharge hydrograph at the upstream end of the Agly main channel. The calibrated Manning coefficients vary from $0.0125 \mathrm{~s} / \mathrm{m}^{1 / 3}$ in the river at the crossing of the town of Rivesaltes to $0.14 \mathrm{~s} / \mathrm{m}^{1 / 3}$ in the built-up areas. The Manning coefficient values in the floodplain do not impact the results significantly because of the influence of the embankments and drainage ditches crossing the floodplain partly in a direction normal to the main flow. The Manning coefficient value in the main channel was adjusted carefully to provide peak water elevations close to flood marks on both banks of the main channel knowing that only a discharge of about $1500 \mathrm{~m}^{3} / \mathrm{s}$ should be considered between the levees. The sediment diameter is set to $0.1 \mathrm{~mm}$ for both the levee and the floodplain considering that, for both, sediment material is alluvial deposits from Agly River. The beginning of the breaching process is set at 09:00 am on November 13, immediately after the second flood peak (Figure 1). Depending on the calculation runs, the breach bottom can be eroded down to $3.4 \mathrm{~m} \mathrm{A.S.L} \mathrm{(land} \mathrm{elevation} \mathrm{at} \mathrm{the} \mathrm{toe} \mathrm{of} \mathrm{the} \mathrm{levee)} \mathrm{or} \mathrm{to} 2.4 \mathrm{~m} \mathrm{A.S.L.} \mathrm{Similarly,} \mathrm{the} \mathrm{calculation}$ included or not a potential erosion of the flood plain up to $1 \mathrm{~m}$. The coefficients $M$ and $\alpha$ are set to standard values of $0.003 \mathrm{~mm} / \mathrm{s}$ and $0.01 \mathrm{~mm} / \mathrm{s}$, respectively. The dimensionless critical shear stress (i.e. critical Shields number) is set to a standard value of 0.047 . At the breach location, the levee crest is assumed to be down by about $0.7 \mathrm{~m}$ at the elevation of $6 \mathrm{~m}$ A.S.L.

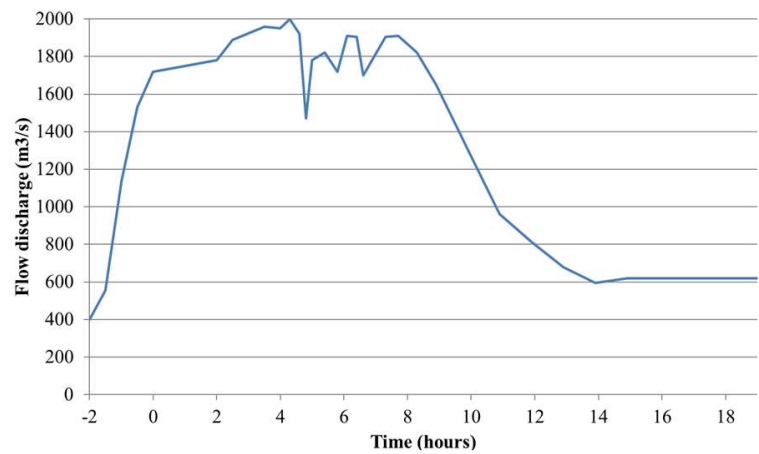

Figure 1. Hydrograph upstream from Agly numerical model (the time 0 means 0 P.M on November 13).

Three meshes are used with an average cell size of 100, 20 or $5 \mathrm{~m}$ (about 2000 cells added in this latter case) in the area downstream from the breach (Figures 2 to 4), respectively. For the breach width less than 50 $\mathrm{m}$, the two coarse mesh models are using three hydraulic structures located on three edges, thus defining a kind of trapezoidal shape while nine structures are used in case of the $5 \mathrm{~m}$ size.

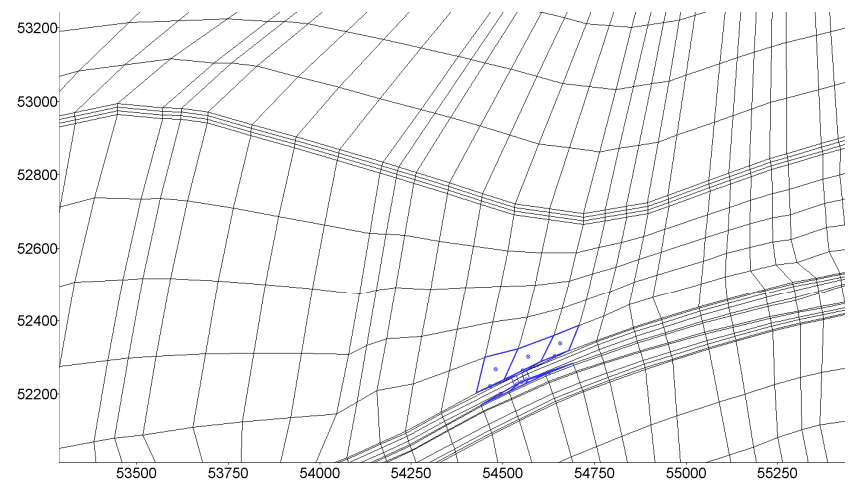

Figure 2. Calculation mesh for a $100 \mathrm{~m}$ cell size (zoom around the breach with location of breach hydraulic structures in blue). 


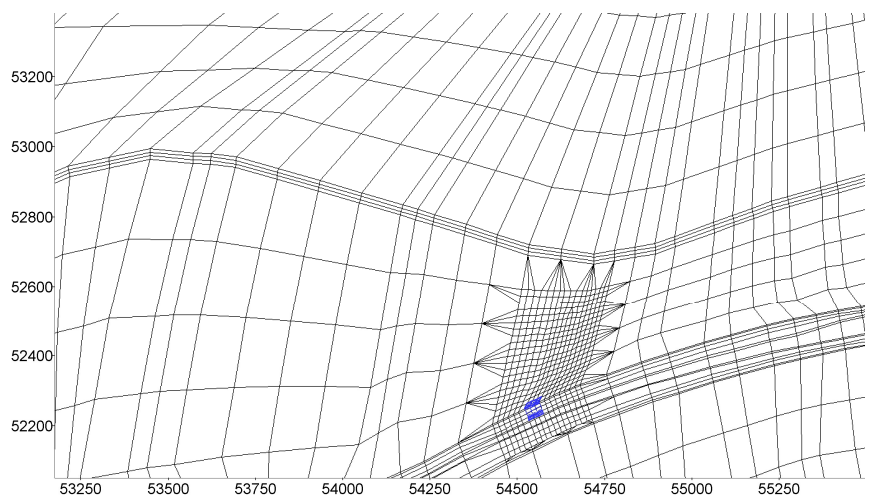

Figure 3. Calculation mesh for a $20 \mathrm{~m}$ cell size (zoom around the breach with location of breach hydraulic structures in blue).

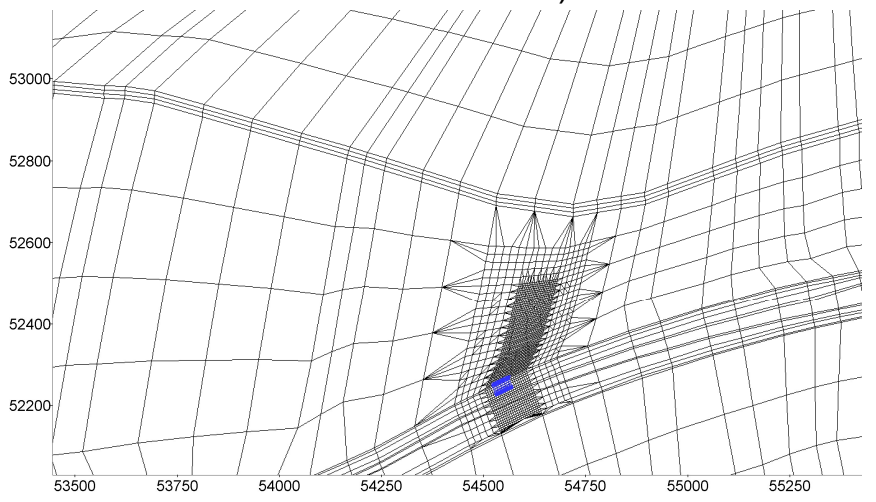

Figure 4. Calculation mesh for a $5 \mathrm{~m}$ cell size (zoom around the breach with location of breach hydraulic structures in blue).

\subsection{Laboratory experiments at EDF laboratory}

These laboratory experiments (Rifai, 2018; Rifai et al., 2018) concern a horizontal $1.8 \mathrm{~m}$ wide channel with the right side constituted by a $0.3 \mathrm{~m}$ high levee protecting a flat floodplain of same elevation as the channel bottom (Figure 5). These experiments were selected because they represent conditions opposite to the field case: the input discharge is constant, thus the levee can be eroded on a long distance and the upstream flow discharge can be nearly totally deviated to the breach. Among all the runs of which the data are available (Rifai et al., 2019), three runs were selected for three different constant upstream flow discharges $(0.072 ; 0.099$; $0.125 \mathrm{~m}^{3} / \mathrm{s}$ respectively) and either a fixed bottom except for the levee (runs 36, 38, 39 respectively) and a bottom (of levee and floodplain) that can be eroded up to $0.1 \mathrm{~m}$ (runs $52,53,54$ respectively). In all the six runs, the sediment diameter is about $1 \mathrm{~mm}$ and the downstream condition for the main channel is a perforated plate that permits to the flow to remain distributed all over the channel section for any water elevation. The floodplain is horizontal, $1.7 \mathrm{~m}$ wide and $7 \mathrm{~m}$ long (as long as the part of the levee that can be eroded) and water can fall freely to a drainage channel on the three opened sides. In order to avoid a sliding of the levee sides, the levee is drained at the toe on the floodplain side and it was checked that the drainage outflow remains small compared to the breach discharge.

The calculation mesh includes 15,704 squared cells with $0.05 \mathrm{~m}$ long edges. The coefficients $M$ and $\alpha$ are set to $0.002 \mathrm{~m} / \mathrm{s}$ and 0.01 . The very high value of $M$ (which is estimated from measurements of the erosion rate of the material) is linked to the lack of cohesion of the material; alternatively, a value of $M$ divided by $10(0.0002$ $\mathrm{m} / \mathrm{s}$ ) was tested. The dimensionless critical shear stress is set to 0.047 . At the breach location, the crest of the levee is assumed to be down by about $0.02 \mathrm{~m}$ at the elevation of $0.28 \mathrm{~m}$ on an initial breach width of $0.1 \mathrm{~m}$ (three nodes of the levee crest are set down) corresponding to the experimental initial breach width. The initial water elevation is assumed to be nearly $0.3 \mathrm{~m}$. 


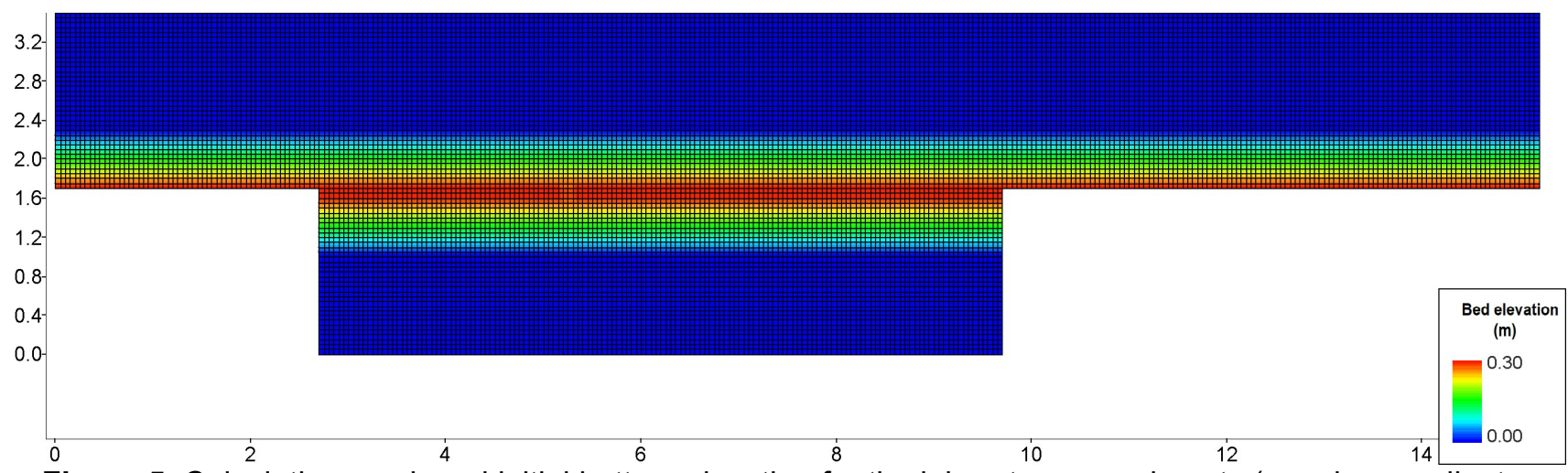

Figure 5. Calculation mesh and initial bottom elevation for the laboratory experiments ( $x$ and y coordinates are in $\mathrm{m}$ ).

\section{RESULTS}

\subsection{Agly levee failure}

The first results are the breach hydrographs that are the main factor for flood propagation downstream. Clearly, if the breaching is calculated using the sediment transport model, the breach development is very limited while the use of the breach model provides discharge hydrographs with a peak between 50 and $150 \mathrm{~m}^{3} / \mathrm{s}$ (Paquier, 2019), the latter value being coherent with the observations. The breach model favors the breach deepening during the first stage of erosion; then, the water depth over the breach bottom is rapidly increasing. For the sediment transport model, the erosion occurs all over the breach width and rapidly, because of the decreasing flow in the Agly main channel, the water depth over the breach bottom is not enough for erosion; if the erosion rate is multiplied by $10(M=0.03 \mathrm{~mm} / \mathrm{s}$ instead of $0.003 \mathrm{~mm} / \mathrm{s}$, denoted "linear fast" in Table 1), then, the breach bottom is going down faster than the water surface and the erosion can develop up to the maximum breach depth.

Table 1. Breach widths in case of the use of breach model

\begin{tabular}{cccccc}
\hline Run & Erosion type & $\begin{array}{c}\text { Mesh size } \\
(\mathrm{m})\end{array}$ & $\begin{array}{c}\text { Floodplain erosion } \\
\text { permitted }\end{array}$ & $\begin{array}{c}\text { Final breach } \\
\text { width }(\mathrm{m})\end{array}$ & $\begin{array}{c}\text { Time of final } \\
\text { breach width }\end{array}$ \\
\hline 5PBS & Linear & 5 & NO & 15 & $09: 30$ \\
\hline 5PBS1 & Linear & 5 & YES & 20 & $10: 38$ \\
\hline 5RBS1 & Linear fast & 5 & YES & 35 & $11: 00$ \\
\hline 5MBS & $\begin{array}{c}\text { Meyer-Peter and } \\
\text { Müller }\end{array}$ & 5 & NO & 5 & $09: 55$ \\
\hline 5MBS1 & $\begin{array}{c}\text { Meyer-Peter and } \\
\text { Müller }\end{array}$ & 5 & YES & 9.5 & $12: 00$ \\
\hline 20PBS & Linear & 20 & NO & 27 & $13: 10$ \\
\hline 20PBS1 & Linear & 20 & YES & 45 & $09: 55$ \\
\hline 20RBS1 & Linear fast & 20 & YES & 45 & $09: 40$ \\
\hline 20MBS & Meyer-Peter and \\
Müller $r$ & 20 & NO & 30 & $11: 35$ \\
\hline 100PBS & Linear & 100 & NO & 45 & $09: 55$ \\
\hline 100PBS1 & Linear & 100 & YES & 45 & $10: 00$ \\
\hline 100RBS1 & Linear fast & 100 & YES & 45 & $09: 50$ \\
\hline
\end{tabular}

The second main result (Table 1) is that, for both breach model and sediment transport model, the standard Meyer Peter and Müller equation provides less erosion than the linear model used with the standard values selected for the presented calculations.

Third, if the land can be eroded, the volume of water entering the floodplain is higher but the peak discharge may be higher or lower depending of the other parameters because deposition is also higher if erosion is higher and deposits can limit the peak flow; nevertheless, if the breach can also deepen to $1 \mathrm{~m}$ below the initial land elevation, the peak breach discharge is nearly always increased (Figure 6) and the limit of $1 \mathrm{~m}$ is reached. One can note also that the peak flood elevation may be increased or decreased in case of simulating land erosion because locally there will be either erosion or deposit at the time of the peak, which will change bottom elevation and thus peak water elevation even if peak water depth is similar. 


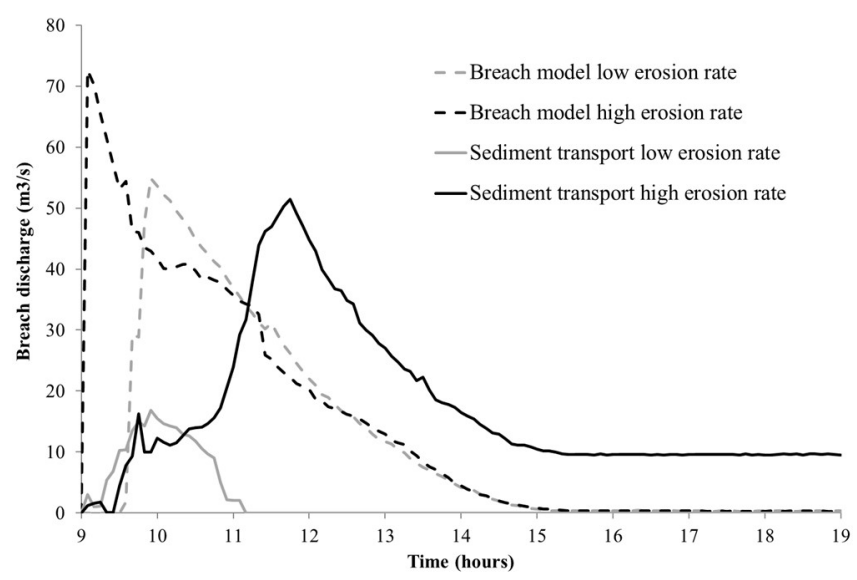

Figure 6. Agly case- Breach discharge hydrographs for $5 \mathrm{~m}$ mesh, erodible bottom and linear erosion (Eq. [1]).

Fourth, the mesh influenced the results even if the breach description is similar (cases of 20 and $100 \mathrm{~m}$ ), particularly, the peak breach discharge (Figure 7) and the breach width (Table 1) although the flow pattern is very similar and the maps of water elevations or erosion depths are very similar (Figures 8, 9 and 10). Using the breach model, the $5 \mathrm{~m}$ mesh size provides narrower breaches if the calculation at the change from one hydraulic structure to the other one starts with the new structure with bottom at the crest of the levee because the water elevation becomes rapidly lower; however, this bias disappears (but erosion is still more progressive) if the new structure starts with bottom elevation equal to the previous one or the final elevation if higher.

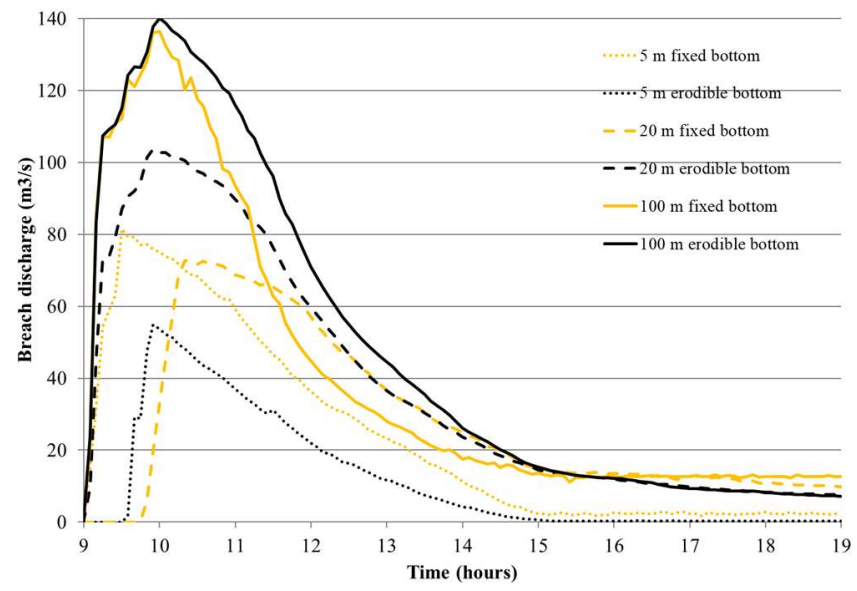

Figure 7. Agly case- Breach discharge hydrographs for various meshes (breach model with linear erosion)

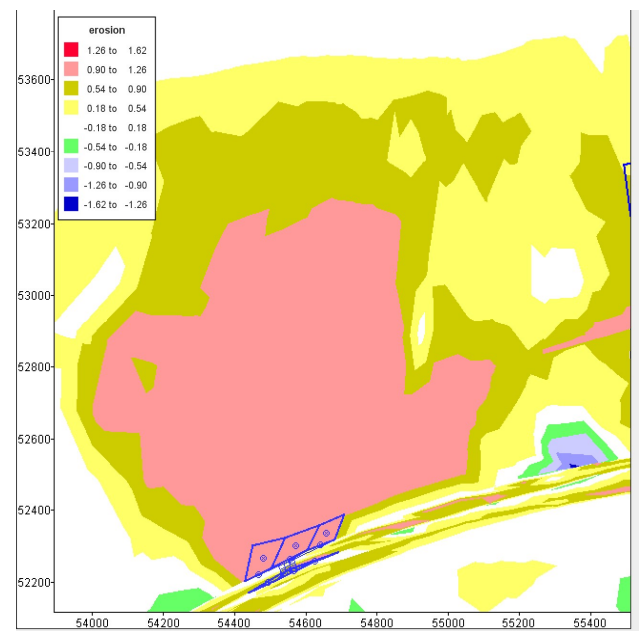

Figure 8. Agly case - Erosion depths for the $100 \mathrm{~m}$ mesh with breach model (high erosion rate). 


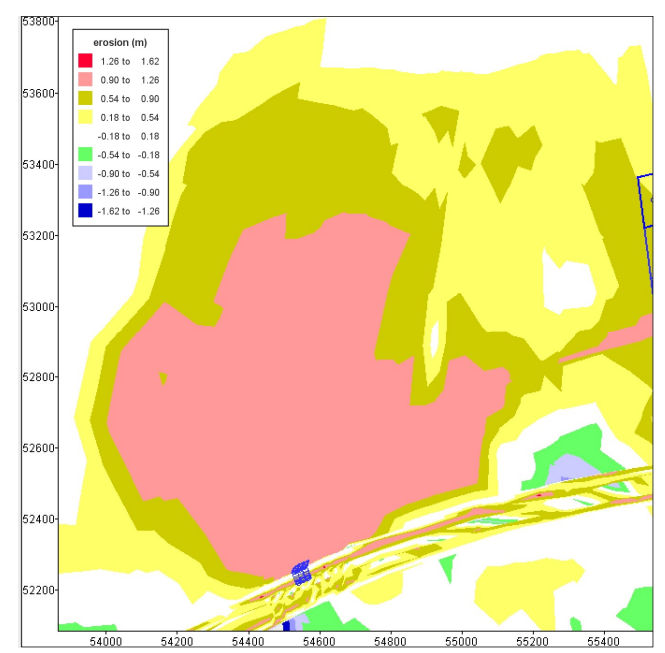

Figure 9. Agly case- Erosion depths for the $20 \mathrm{~m}$ mesh with breach model (high erosion rate).

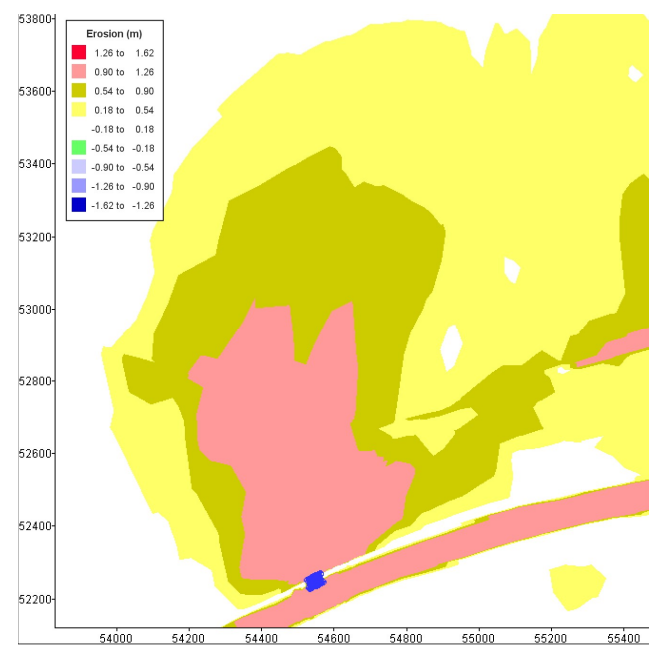

Figure 10. Agly case - Erosion depths for the $5 \mathrm{~m}$ mesh with breach model (high erosion rate).

\subsection{Laboratory experiments}

The comparisons for these experiments are concentrated on the effect of various flow discharges, of the erosion of the floodplain and the selection of breach model versus sediment transport model. Both breach flow discharge and breach width are investigated although the breach discharge hydrograph is related closely to the breach width evolution. In fact, one can note that, for the case of erodible bottom, the material coming from the erosion of the main channel is not evacuated by the breach and only at the downstream end of the breach, the layer of sand is completely eroded; this process is not simulated and oppositely to the case of non-erodible bottom, the simulated shape of the breach is far from the experimental one (Figures 11 to 14). In order to obtain close results for breach widening in the calculation, it is necessary to limit the erosion of the main channel bottom (Figure 14), which does not permit to produce deposits at the upstream end of the breach.

For the case of fixed bottom, even if the final breach width is similar to the observed one, the measured breach is located more downstream along the main channel, which agrees with the shape of the banks of the breach that show, in the experiments, a stronger effect in the direction of the main channel flow. 


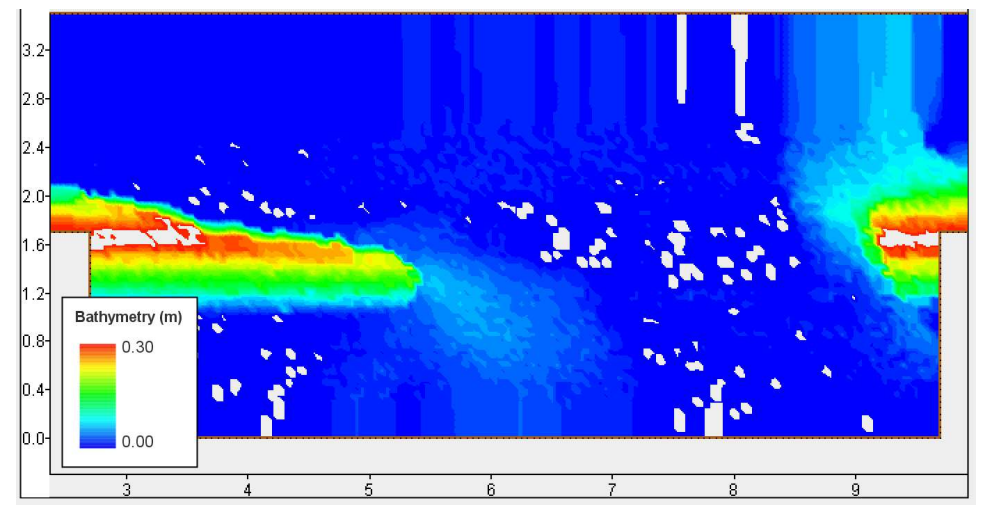

Figure 11. Final bottom elevations - measurements of run 39 of EDF experiments (only dike is erodible).

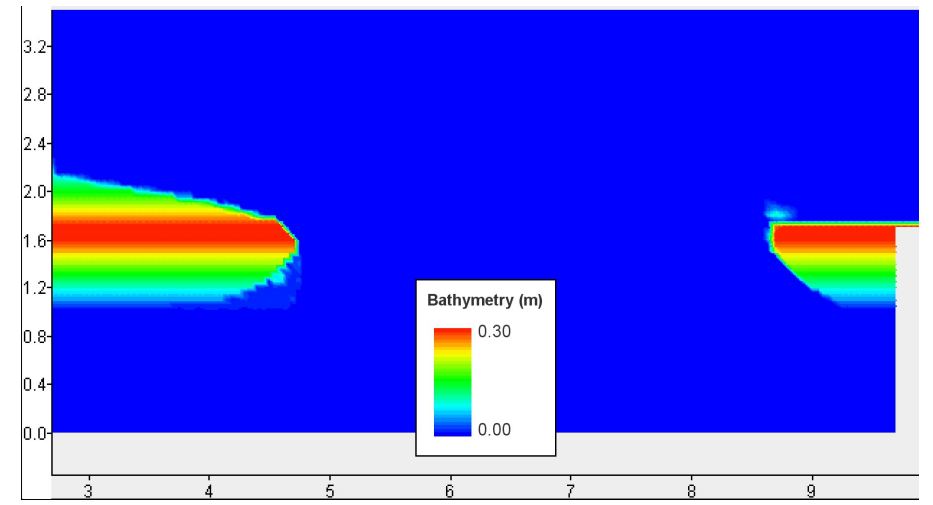

Figure 12. Final bottom elevations - calculation results (sediment transport model with linear erosion) for run 39 of EDF experiments.

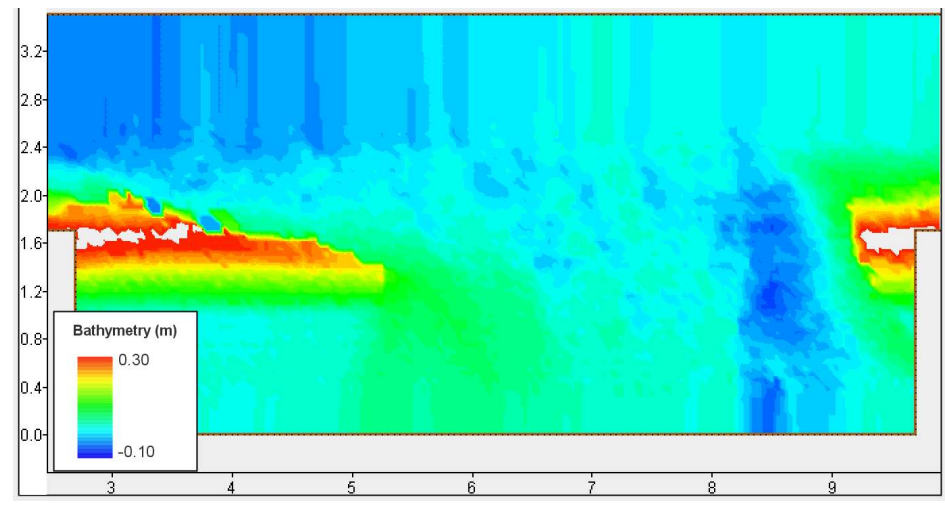

Figure 13. Final bottom elevations - measurements of run 54 of EDF experiments (channel and floodplain beds are erodible over $0.10 \mathrm{~m}$ ).

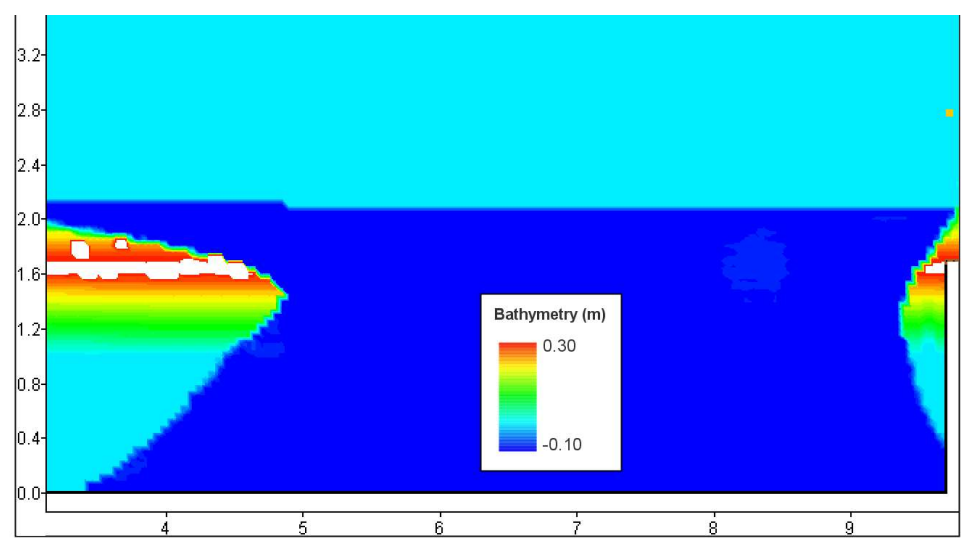

Figure 14. Final bottom elevations - calculation results (sediment transport model with linear erosion) for run 54 of EDF experiments. 
As pointed out by Rifai et al. (2017), the evolution of the breach is split into a first step with fast evolution and a second step of slow breach development up to nearly the whole length of the levee for the six runs investigated here. These two stages can be found in the calculation results but calculation shows a levee erosion that stops much earlier than experiments. In fact, using the Meyer-Peter and Müller equation, generally, the breach does not develop: either, there is no erosion because the water depth of $0.02 \mathrm{~m}$ is not enough or if bottom erosion starts, the walls are not eroded, which means the breach does not widen. With the linear equation [1], generally, erosion occurs but is more or less rapidly limited because the head between the main channel and the floodplain is reduced as more flow is diverted to the floodplain and induced a relatively high water depth in the floodplain. In fact, the breach model produces very rapid breach opening and then stops (Table 2); then, one can conclude that it simulates only the first step of the breach development. In order to check this assumption, the calculations with the breach model were performed again with erosion coefficient $M$ divided by 10; figure 15 shows that a similar behavior is observed although the breach development is slowed down and prolonged. Oppositely, the sediment transport model produces a more progressive widening and is closer to experiments.

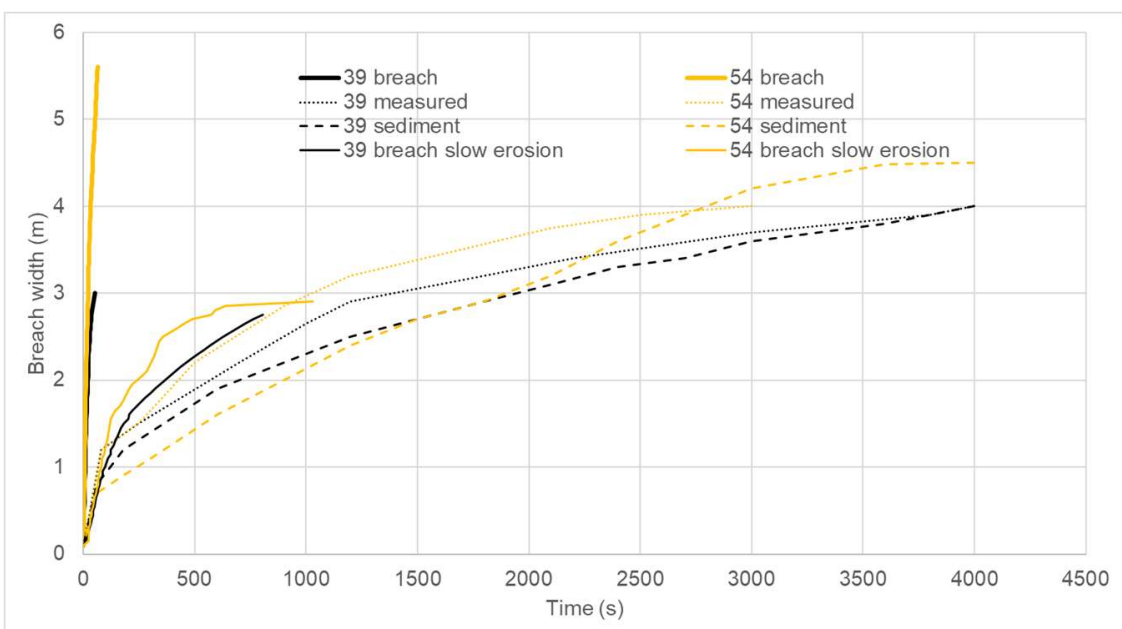

Figure 15. Breach width evolution for the runs with high discharge (39 with fixed bottom and 54 with erodible bottom)

Table 2. Final breach discharges and breach widths for the laboratory experiments

\begin{tabular}{lccccc}
\hline Run & $\begin{array}{c}\text { Upstream flow } \\
\text { Discharge }\left(\mathrm{m}^{3} / \mathrm{s}\right)\end{array}$ & $\begin{array}{c}\text { Erosion } \\
\text { model }\end{array}$ & $\begin{array}{c}\text { Peak breach } \\
\text { discharge }(\mathrm{m} 3 / \mathrm{s})\end{array}$ & $\begin{array}{c}\text { Final breach } \\
\text { width }(\mathrm{m})\end{array}$ & $\begin{array}{c}\text { Time of final breach } \\
\text { width }(\mathrm{s})\end{array}$ \\
\hline 36 measured & 0.072 & & 0.063 & 3.9 & 7800 \\
\hline 36 calculated & 0.072 & Breach & 0.062 & 2.6 & 34 \\
\hline 38 measured & 0.099 & & 0.085 & 4 & 4000 \\
\hline 38 calculated & 0.100 & Breach & 0.079 & 2.8 & 43 \\
\hline 39 measured & 0.125 & & 0.107 & 4 & 2300 \\
\hline 39 calculated & 0.125 & Breach & 0.095 & 3 & 4000 \\
\hline 39 calculated & 0.125 & Sediment & 0.110 & 4 & 7800 \\
\hline 52 measured & 0.072 & transport & 0.064 & 3.8 & 80 \\
\hline 52 calculated & 0.072 & Breach & 0.070 & 4 & 4200 \\
\hline 53 measured & 0.100 & & 0.088 & 7 & 3000 \\
\hline 53 calculated & 0.100 & Breach & 0.097 & 4 & 64 \\
\hline 54 measured & 0.12 & & 0.105 & 5.5 & 4000 \\
\hline 54 calculated & 0.125 & Breach & 0.115 & 4.5 & \\
\hline 54 calculated & 0.125 & Sediment & 0.122 & & 4 \\
\hline
\end{tabular}

\section{CONCLUSIONS}

For the field case, the short overtopping duration involves that the results are very sensitive to the erosion parameters associated to the dike breaching, particularly the shear stress necessary for the initiation of erosion. The breach development depends on the modelling approach that can favour either the breach deepening or widening. With a fast breach deepening, the breach peak flow is high whereas a high breach widening leads to a peak flow reduced by more than $90 \%$ because the breach stops developing with the decrease of water elevation in the main channel. 
The laboratory experiments represent a long flood event that can lead to a total erosion of the dike over a long distance with a large part of the upstream flow deviated into the breach. Oppositely to the field case, the evolution with the breach model or without are similar although there is a faster evolution in the first erosion step with the breach model and this evolution is also much faster than the measurements, which means that the use of the breach model should not be recommended in this case oppositely to the field case.

\section{ACKNOWLEDGEMENTS}

The second author acknowledges the support of the Fonds Européen de Développement Régional (FEDER) and the Association Nationale de Recherche et de la Technologie (ANRT). The laboratory experiments were performed by Ismail Rifai in the framework of his Ph.D thesis. The technical and scientific support of University de Liège (B. Dewals, S. Erpicum, P. Archambeau, M. Pirotton) is acknowledged.

\section{REFERENCES}

ASCE/EWRI Task Committee on Dam/Levee Breaching. (2011). Earthen embankment breaching. Journal of Hydraulic Engineering. 137 (12), 1549-1564.

Cantero-Chinchilla, F.N., Castro-Orgaz, O., Schmocker, L., Hager, W.H., and Dey, S. (2018). Depth-averaged modelling of granular dike overtopping. Journal of Hydraulic Research, 56 (4), 537-550, DOI: 10.1080/00221686.2017.1399933.

El kadi Abderrezzak, K., Paquier, A., and Mignot, E. (2009). Modelling flash flood propagation in urban areas using a two-dimensional numerical model. Natural Hazards, 50 (3), 433-460.

Meyer-Peter, E., and Müller, R. (1948). Formulas for bed-load transport. Proc. $2^{\text {nd }}$ IAHR Meeting, Stockholm, Sweden, 2, 39-64.

Paquier, A. (2007). Testing a simplified breach model on Impact project test cases. In: G.D. Silvio and S. Lanzoni (Ed.), XXXII IAHR Congress, Venice, Italy.

Paquier, A. (2013). Logiciel Rubar 20. Notice d'emploi. Irstea, Villeurbanne, France.

Paquier, A. (2015). Comparison of three methods assessing the inundation caused by the erosion of an embankment. La Houille Blanche, 4, 32-38. DOI: 10.1051//hb/20150043.

Paquier, A. (2019). Modelling the development of a breach caused by overtopping and associated sediment transport. Proc. Conference Digues 2019, Aix-en-Provence, France. DOI: 10.5281/zenodo.2530126.

Paquier, A., Fang, Z.X., and Rouch, B. (2002). Hydraulic modelling of the 1999 flood in the lower reach of Agly river. In: Y. Zech (Ed.), Proc. $1^{\text {st }}$ International Conference on Fluvial Hydraulics (River Flow), Louvain la Neuve, Belgium.

Rifai, I., Erpicum, S., Archambeau, P., Violeau, D., Pirotton, M., El Kadi Abderrezzak, K., and Dewals, B.J. (2017). Overtopping induced failure of non-cohesive, homogeneous fluvial dikes. Water Resources Research, 53 (4), 3373-3386.

Rifai, I., El kadi Abderrezzak, K., Erpicum, S., Archambeau, P., Violeau, D., Pirotton, M., and Dewals B. (2019). Flow and detailed 3D morphodynamic data from laboratory experiments of fluvial dike breaching. To appear in Scientific Data.

Rifai, I., El kadi Abderrezzak, K., Erpicum, S., Archambeau, P., Violeau, D., Pirotton, M., and Dewals, B. (2018). Zenodo DOI: 10.5281/zenodo.1492145.

Rifai, I. (2018). Overtopping induced fluvial dike breaching. Ph.D thesis, Université Paris-Est and Université de Liège.

Zhong, Q., Wu, W., Chen, S., and Wang, M. (2016). Comparison of simplified physically based dam breach models. Natural Hazards, 84: 1385-1418. DOI: 10.1007/s11069-016-2492-9. 